\title{
Чому Москва боїться українського друкованого слова, або Історія про те, як імперська влада через заборону книг знесилювала дух російських українців
}

\author{
Микола Тимошик, \\ д-р філол. н, проф. \\ Київський національний \\ університет культури і мистецтв \\ вул. Є. Коновальця, 36, \\ 01601, Київ, Україна \\ e-mail:nkin@ukr.net \\ ORCID ID 0000-0002-7011-3022 \\ (C) Тимошик М., 2018
}

Феномен справді незбагнений: кілька мільйонів украйнців, які віддавна мешкають на неозорих просторах Росії як її громадяни, нібито добровільно відмовилися від свого національного «я». Вони давно вже змирилися з тим, що в тій державі немає шкіл чи бодай класів із українською мовою навчання, заникли українознавчі кафедри при університетах. На противагу українським реаліям, де російської більш ніж треба, там не друкуються українською газети, журнали, книги, не мовить мовою їхніх пращурів радіо, телебачення. Упродовж останніх років українці Москви, як і всієї Росії, мовчазно спостерігали за тим, як у їхній столиці конав останній оберіг генетичної пам'яті - Українська бібліотека в Москві.

Доля української книги в Росії в цілому і української бібліотеки в Москві зокрема - цікаве i,на жаль, не пізнане й не поціноване досі явище в історії української культури, яке не можна розглядати поза контекстом конкретних подій тієї чи іншої історичної доби.

Варто згадати хоча б дивовижні за змістом і художнім оформленням видання друкарні Києво-Печерської лаври, які протягом тривалого часу, за висловом Івана Огієнка, буквально “сунули на Москву” могутнім потоком, витісняючи книги тамтешніх друкарень.

Саме авторитет київських книг і, передусім, їхня тогочасна українська мова, яка була, згідно з констатацією Петра I, “несогласна с московскими печатми”, спонукали незабаром уряд Російської імперії вдатися до жорстоких і нечуваних досі в історії цивілізаційного поступу заходів: українську книгу в імперії протягом століть заборонялося друкувати й поширювати. 
Не стала винятком у цій серії антиукраїнських заборонницьких заходів і доба щойно минулого XX та початку XXI століть.

\section{Українці у Росії у 20-х роках були сміливіші}

Витоки Української бібліотеки в Москві беруть початок від 1918 року, коли за ініціативою національно свідомої частини української інтелігенції було створено Український клуб імені Тараса Шевченка. Саме довкола цієї громадської організації почало активно об’єднуватися московське українство. Так постали в Москві культурні заклади української громадськості - театр, хорова студія, школа, дитячий садок i бібліотека.

Тоді ж були здійснені спроби відновлення видавничої діяльності, адже ще свіжою в пам'яті була результативна робота редакції журналу “Украинская жизнь”, яка під проводом Симона Петлюри протягом 1912-1917 років об’єднала довкола себе провідних українських діячів і готувала до друку насичений за змістом і великий за обсягом щомісячник. Вершиною видавничої діяльності “Украинской жизни” стала книга “Украинский вопрос”, що витримала в Москві два видання (1914 i 1917), а в Україні перевидана в українському перекладі автора цих рядків лише через 80 років.

Документи московських архівів, які авторові цих рядків вдалося опрацювати ще до початку російсько-української війни на Донбасі, засвідчують, як непросто давалися українцям спроби ствердження свого духу на московських теренах навіть у найсприятливішу пору реалізації радянською владою головних засад і принципів так званої ленінської національної політики, в основу якої було покладено нібито рівноправність усіх радянських народів та повне задоволення їхніх культурних потреб.

Перша загроза вільному існуванню українських організацій та установ у Москві виникла ще в 1922 році - за кілька місяців до проголошення СРСР. Тоді за розпорядженням Московського відділу народної освіти було припинене фінансування українського театру, який, до речі, користувався великою популярністю серед глядачів, а приміщення, яке він займав і в якому містилися український клуб та бібліотека (вулиця Тверська №37), було передане театру імені Комісаржевської. Щоправда, українцям залишили тимчасово в цьому приміщення чотири кімнати, в одну з яких заледве вмістилися бібліотечні фонди.

Щоб не перетворити бібліотеку, де вже налічувалося 17 тисяч томів українських книг, “в архів для любителів”, керівництво українського клубу зверталося в різноманітні московські установи з проханням виділити для цих потреб інше приміщення. Паперова тяганина 3 розв’язанням цього питання тривала... шість років. Справа, здавалося б, зійшла з мертвої точки, коли після письмового звернення тодішньо- 
го голови Раднаркому УРСР Чубаря до голови Москради 20 квітня 1928 року для українських організацій мало бути виділене приміщення колишнього театру “Семперанте”. Однак, незважаючи на позитивну резолюцію на цьому листі заступника Голови Москради товариша Волкова, зазначене приміщення одержав клуб єврейського земляцтва.

I ось на фоні таких реалій - відсутність читального залу, тісноту, припинення фінансування з боку державних органів (в штаті залишалася одна одиниця з оплатою лише за три години робочого часу в день) - українська бібліотека в Москві продовжувала працювати. A ïï ентузіасти й захисники продовжували оббивати пороги високих партійних і радянських постанов.

18 травня 1929 року в приміщенні клубу ім. Кухмістерова відбуваються велелюдні збори українських робітників, службовців і студентів Москви (за архівною довідкою, там були присутніми 2000 наших земляків). Варто навести короткий витяг з резолюції зборів:

«... Добиватися від Москради надання приміщення для клубу, субсидї клубу від ММРПС, прийняття за утримання МОНО (Московського відділу народної освіти м. т.) бібліотеки клубу, включення в бюджет нКосвіти Драматичної і Хорової студї̈ та органівації в Москві української школи цй дитячого садка)».

У травні делегація українських діячів потрапила на прийом з цього питання до голови Москради тов. Уханова, а влітку того ж року, під час роботи з’їзду Рад, зустрілася з Головою ВЦВК і ЦВК УРСР Г. Петровським. Не дочекавшись відповіді, представники української громадськості вже письмово повторно звертаються до Петровського і Чубаря 3 пропозицією “про якнайшвидше задоволення потреб української громадськості і про притягнення до відповідальності осіб, які винні в тяганині”.

Спеціальна нарада в Московському комітеті ВКП(б), яка скликалася незабаром, вселяла українцям певні надії. Вже були складені кошториси на утримання українського клубу, бібліотеки, драматичної студії та хорової капели. Йшлося навіть про виділення приміщення. Але й те рішення залишилося лише на папері.

Вершиною кількарічної тяганини стала заява інструктора відділу національних меншин Московської міської профспілки. Цей документ подаю мовою оригіналу:

\footnotetext{
"Все укранцы понимают украинсткий язык и поэтому нужды в существовании отдельного украинского клуба нет".
}

Саме на ту пору - кінець двадцятих років - фонди бібліотеки поповнилися ліквідованими українськими відділами з бібліотеки 
Тімірязєвської сільськогосподарської академії, бібліотеки Земляцтва студентів України, а також 13 пересувних українських бібліотек (у середньому по 200 книг у кожній).

Незважаючи на те, що “бібліотека себе не афішувала через вивіски, оголошення і пресу, вже тепер вона переросла усі норми спеціального й технічного забезпечення”. Про це йдеться, зокрема в листі бібліотекаря (підпис нерозбірливий) до московського відділу Комісаріату національних меншин від 1 червня 1929 року. Автори звернення доводили необхідність виділення цій культурній установі трьох штатних одиниць: бібліотекаря з повним робочим навантаженням, його помічника та технічного працівника.

\section{За свої права не просили, а вимагали}

у Центральному державному архіві Московської області Росії (ЦДАМО Росії) віднайдено ще один документ, який засвідчує наполегливість і сміливість української громади в Москві добиватися своїх культурних прав. Це протокол спеціального засідання Центрального українського клубу імені Т. Г. Шевченка, де розглядалося питання про становище з українською бібліотекою. В постанові засідання йшлося про те, щоб “просити Губполітраду МОНО прислати спеціальну комісію для обстеження бібліотеки і встановлення суми коштів, необхідних на її утримання”.

А ось на цьому документі варто зупинитися окремо. Варто звернути увагу і на цей документ. Йдеться про лист, надісланий від Українського клубу імені Т. Г. Шевченка, Земляцтва пролетарських студентів України та Товариства друзів українського театру відразу на кілька високих урядових і партійних адрес. Варто перелічити ці адреси, аби переконатися в серйозності намірів авторів листа остаточно з'ясувати суть питання, розв’язання якого свідомо затягувалося упродовж багатьох років. Абревіатури й назви організацій подаю мовою оригіналу:

"В рабоче-крестьянськую инспекцию СССР.

Копии: РКИ РФСФР - тов. ЯковлевУ; РКИ УССР - тов. Затонському, тов. Орджоникидзе; Совнарком СССР - тов. Рикову; Совнарком РСФСР - тов. Сирцову, Совнарком УССР - тов. Чубарю, ВЦИК - Президиуму; цИК РСФСР - тов. Калинину; цИК УССР - тов. Петровському; НКпрос РСФСР тов. Бубнову; НКпрос УССР - тов. Скрипнику; Совет Национальностей ВциКа - тов. Смидовичу; Моссовет - тов. Уханову; МособлРКИ; ЦК ВКП(б) - Молотову, Кагановичу; ЦК КП(б)У - тов. Косиору; МК ВКП(б) - тов. Бауману; Постпредство УССР - тов. Круцко; Совнацмен МОНО; Нацмен МК - тов. Иткиной; ВЦСПС - Президиуму; ВЦСПС - тов. Акулову; МГСПС - президиуму МГСПС - Нацмен». 
Текст цього рідкісного і мало знаного навіть у колі фахівців документа займає п’ять сторінок машинопису, в якому коротко викладена суть звернення (про відсутність підтримки українських культурних установ, зокрема бібліотеки, в РРФСР з боку державних органів), скрупульозно описана хронологія безрезультатних звертань до різноманітних високопосадових чиновників і сподівання якнайшвидшого розв’язання цієї проблеми.

Ось окремі витяги з цього документа:

"Вопрос об организации культурных учреждений, обслуживающих украинское население, могущих пронести в гущу украинского населения РФССР те достижения украинской культуры последних лет, которые своим размахом привлекают внимание всех общественых кругов всего Советского Союза - несомненно должен был бы стоять в центре внимания соответствующих организаций РСФСР. В действительности мы имеем следующее: культурные учреждения, созданные и поддерживаемые исключительно силами укринской общественности - стоят вне внимания и поддержки соответствующих организаций РСФСР, встречая к себе не только невнимательное, но зачастую пренебрежительное и даже ликвидаторское отношение... (Тут і далі виділення авторів документа - м. т.). Нельзя обойти молчанием также следующие факты, свидетельствующие ○ недопустимом отношении именно к украинской культуре и именно в Москве: ...в Москве другие нацменьшинства - поляки, латыши, евреи - имеют вполне подходящие помещения и дотации от моно - только для украинцев их не хватает».

Наприкінці цього документа автори ставлять адресатам риторичне запитання:

«Добиваться ли далее помощи от советских и профессиональных органов РСФСР в проведении культурной работы среди трудящегося украинского населения РСФСР или свернуть всю работу и установить факт, что работе по проведению украинской культуры в массы рабочих-украинцев на территории РСФСР нет места «за ненадобностью?»

Дата відправлення цього листа за вище зазначеними адресами 4 листопада 1929 року.

Чи знали його автори, що вже тоді в Москві й в Україні все сильніше розкручувався маховик сталінських репресій, серед яких чи не найвідчутнішого удару зазнає українство? 
Уже тоді в кабінетах ДПУ поспіхом, дико й цинічно фабрикувалася справа “Спілки Визволення України”, матеріали якої склали більше 250 томів.

На жаль, за наявними архівними матеріалами не вдалося простежити подальшої долі тих, хто підписав цього листа. Серед нерозбірливих підписів прочитуються декілька - Вакула, Чоботарьов, Нахімов. Скоріш за все, вони, як і десятки, сотні тисяч українців, репресованих більшовицькою системою за так званий український буржуазний націоналізм, закінчили свої життя в страшних катівнях ГУЛАГів, розміщених густою сіткою від Соловків до Магадану...

\section{Мандрівка книг з Москви до Львова й назад}

Не вдалося з'ясувати й повної історії самої Української бібліотеки в Москві. Судячи з численних штемпелів, які проставлялися на книгах, що збереглися до наших днів, ця бібліотека все ж якось вижила і в тридцяті роки, без кінця змінюючи свою назву й адміністративне підпорядкування. Ось як змінювалися офіційні назви цієї бібліотеки:

Українська центральна бібліотека в Москві;

Українська бібліотека сільськогосподарського інституту в Москві;

Українська центральна бібліотека при українському клубі в Москві;

Бібліотека земляцтва пролетарських студентів України в Москві;

Українська центральна бібліотека №86 Москви.

Останній архівний документ, який засвідчує офіційний статус цієї бібліотеки як української, датовано 1 січня 1936 року. Тоді вона розміщувалася на вулиці Горького, 37/9 і підпорядковувалася Краснопресненській райраді. Згідно з річним звітом, тут налічувалося 11630 книг, з них українською мовою - 7860. За звітний 1935 рік було видано книг за індивідуальними абонентами 9194.

1937 року будинок на вулиці Горького, в якому кілька кімнат орендував Український клуб та бібліотека при ньому (отож, інше приміщення так і не віднайшлося), був знесений. На цю пору припадає й знищення в Москві різноманітних національних культурологічних товариств. Колись велика й відома далеко поза межами Москви Українська бібліотека стає звичайним відділом бібліотеки №85 Радянського району, знекровлюючись і розгублюючи свою дивовижну колекцію, але все ще залишаючись гордим і нескореним осередком української культури.

У зв’язку з евакуацією в Кзил-Орду Київського і Харківського університетів і створення на їх базі Українського державного університету частину з цих фондів 1943 року переслали з Москви на адресу цього навчального закладу в далекий Казахстан.

Остаточна ж ліквідація залишків Української бібліотеки в Москві припадає на 1949 рік. 
У відповідності з розпорядженням заступника Голови Ради міністрів РФСРР т. Зуєвої від 12 грудня 1949 року в бібліотеці №68 було відібрано 6208 україномовних книг для відправки у Львів тамтешньому університету ім. І. Франка. Українська книга в Москві була визнана, отже, непотрібною.

До Львова ці книги добиралися майже дев’ять місяців. У Фонді архівних документів Бібліотеки української літератури в Москві вдалося віднайти цікавий документ, який варто процитувати повністю мовою оригіналу:

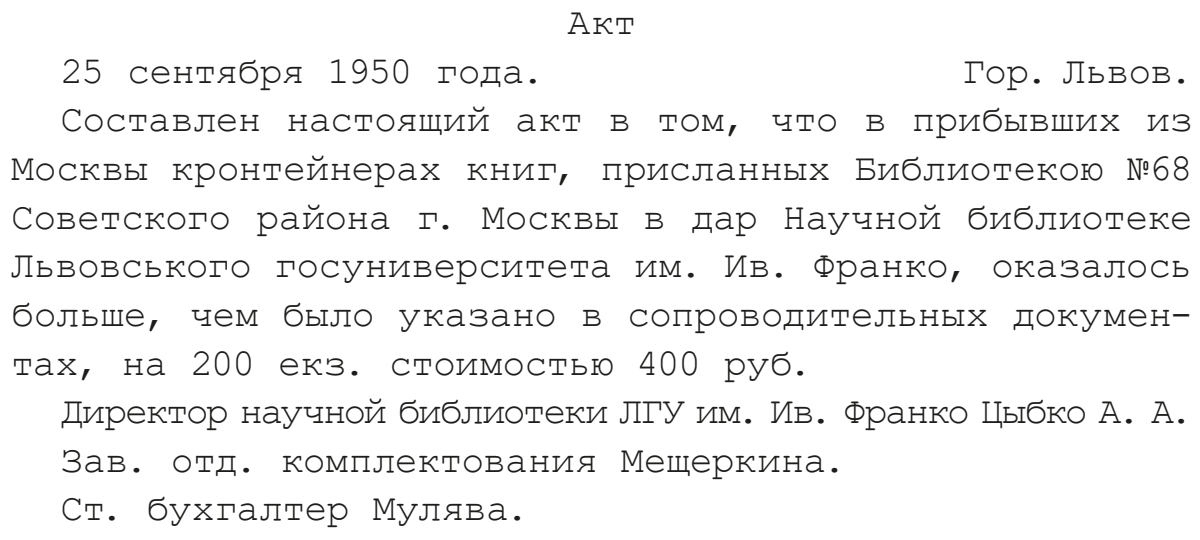

Директор научной библиотеки ЛГУ им. Ив. Франко Цыбко А. А.

Зав. отд. комплектования Мещеркина.

Ст. бухгалтер Мулява.

Хто зна: за іронією долі, а чи за закономірним збігом обставин, але через сорок років працівники наукової бібліотеки Львівського держуніверситету складатимуть акт про повернення до Москви цих книг на адресу правонаступниці Центральної української бібліотеки Москви - Бібліотеки української літератури в Москві, яка відновила свою роботу у грудні 1989 року. Щоправда, цього разу 3 тієї більш ніж шеститисячної колекції вдалося зібрати у Львові лише 1200 примірників - остача пропала чи розіслана через книгообміни...

Ось такою драматичною і хвилюючою є доля одного із сотень, тисяч осередків українського духу поза межами нашої Батьківщини Української бібліотеки в Москві.

\section{Новітні утиски друкованого слова з берегів Дніпра}

Із відновленням Україною незалежності митарства української книжки в Москві та її головної колекції не завершилися

На жаль, низка сторінок цієї історії залишається не з'ясованою. 3 липня 1997 року офіційно цей заклад називався Бібліотека російської та української літератури. I практично відтоді нинішні керівники українських організацій російської столиці за підтримки Посольства України в Москві зверталися в різноманітні високі московські інстанції з двома питаннями, які потребували нагального розв’язання: від- 
новлення статусу цього закладу як самостійної міської бібліотеки та надання належного приміщення для їі роботи.

Необхідність нового приміщення особливо актуальна. Адже вже на початок 2000-х років фонди бібліотеки налічували понад 33 тисячі назви українських книг. Вони мало не щодня збільшувалися. Бо з тих пір на адресу Культурного центру України в Москві продовжували надходити книжкові посилки. I не лише з усіх куточків України, а й від наших земляків у близькій та далекій діаспорах.

За часів президентства Кучми і Януковича з’явився у цій справі ще один незбагнений феномен: українську книгу в Москві не бажали бачити не лише московські політики і держиморди, а й свої, доморощені «державотворці». Так, в архіві Бібліотеки української літератури в Москві довелося бачити немало копій із рясного листування бібліотеки та Посольства України в Москві з посадовцями Державного митного комітету та керівниками Конотопської і Глухівської митниць щодо безпідставного вилучення на цих митницях книг, адресованих Українській бібліотеці в Москві. Ось характерний витяг з листа посольства до митного комітету в Київ:

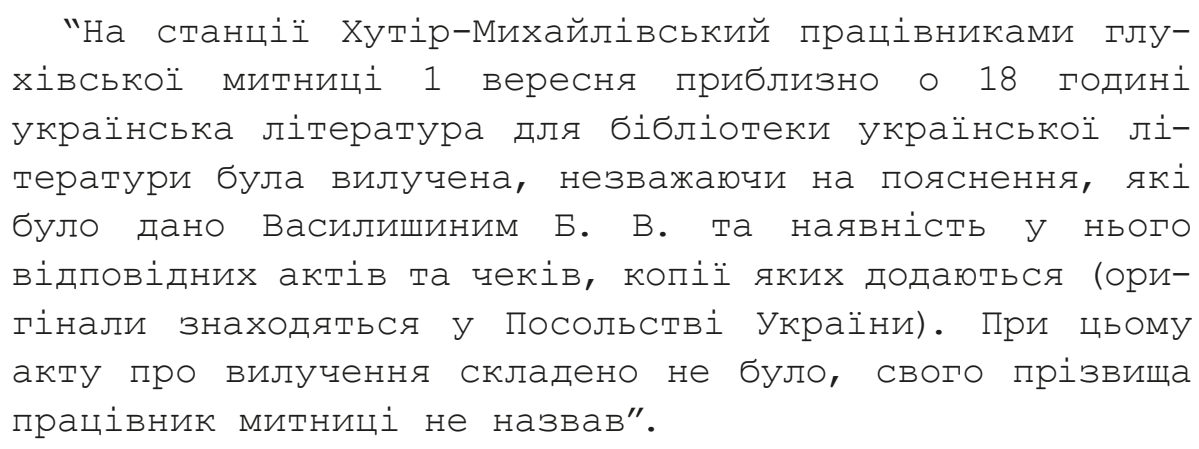

Подія про яку йдеться, сталася 1994 року. А ось ще один приклад. У день презентації в Москві нового україномовного київського журналу “Політика і культура”, відомого в нас як “ПіК” В. Кривенка, в Культурному центрі України в Москві 17 грудня 1999 року стало відомо, що учасники презентації не матимуть можливості потримати в руках це видання - до Москви його не довезли. Кілька пачок цього часопису “арештовано” було на нашій, конотопській, митниці.

...Сумний фінал цієї історії.

У березні 2017 року Українську бібліотеку в Москві, яка брала свій початок від 20-х років XX ст., закрили. Книги спакували і вивезли.

Останню директорку цієї бібліотеки Наталію Шарову засудили на чотири роки. За те, що тримала «екстремістські книги» і за те що «розпалювала національну ненависть до росіян».

Кажуть, історія повторюється. Але вдруге вона стає вже фарсом... 


\title{
WHY IS MOSCOW AFRAID OF A UKRAINIAN WRITTEN WORD? Or, in other words, the story of how the emperial power weakened the spirit of russian ukrainians via forbidding books
}

\author{
Mykola Tymoshyk, \\ Doctor of Philology, Professor \\ Kyiv National University of Culture and Arts \\ Ye. Konovaltsia str., 36 \\ 01601, Kyiv, Ukraine \\ e-mail:nkin@ukr.net \\ ORCID ID 0000-0002-7011-3022
}

The history of the existence of the Ukrainian book in Moscow in general and Ukrainian libraries in particular are analyzed on the basis of archival materials. The timeframe for review is from the 18th century to the first two decades of the twenty-first century.

The little-known fact is emphasized: the power and the authority of the growing number of books that came to Moscow from the printing house of Kyiv-Pechersk Lavra in the fourteenth and the beginning of the eighteenth century were so great that tsar Petro I was forced to issue a special decree (1720) on the prohibition of the issues of this printing center, which came in spelling mismatching that of the Russian language.

Separately, the situation with the Ukrainian book in the capital of Russia in the 20s of the twentieth century is considered. This was the period of its greatest development. In Moscow then there was a powerful public organization - T. Shevchenko Ukrainian Club. Thanks to its efforts, despite the resistance of the official authorities, it became possible to open the Ukrainian library.

The fate of this library is traced here as well: evacuation on the eve of the Second World War to Central Asia, the return of Ukrainian books to the library of Lviv University after the war, the closure of the Ukrainian library in Moscow in 1949.

The author has collected interesting facts about the recent history of the Ukrainian Library in Moscow. It began in the early $90 \mathrm{~s}-$ since the restoration of Ukrainian independence. And it ended in 2017, when Russian authorities finally liquidated the library, and its head, Natalia Sharova, was imprisoned for, as they put it, holding "extremist books" and for "stirring up national hatred for Russians". 